\title{
A CLINICAL STUDY OF EFFECT OF FIELD BLOCK ON INGUINAL HERNIORRHAPHY IN AN OUTPATIENT SURGERY
}

\author{
Velagalaburre Yalappa Srinivasa ${ }^{1}$, Thuraganur Kapanigowda Shashikala²
}

${ }^{1}$ Associate Professor, Department of Anaesthesiology, K. R. Hospital, Mysore Medical College and Research Institute, Mysore. ${ }^{2}$ Associate Professor, Department of Anaesthesiology, K. R. Hospital, Mysore Medical College and Research Institute, Mysore.

\section{ABSTRACT}

Aim of the study is to evaluate effectiveness of lignocaine with adrenaline for field block as well as for day care surgery and its complications.

\section{MATERIAL AND METHODS}

One hundred patients aged between 18 to 60 years of ASA class I and II posted for elective inguinal herniorrhaphy, agreeing and co-operative for inguinal field block.

\section{RESULTS}

An $80 \%$ patients had excellent, $15 \%$ had good, $2 \%$ had fair, $3 \%$ had poor quality of analgesia. Using modified Aldrete score. ${ }^{1}$ fit for discharge studied; 12 patients became fit for discharge in 60 mins; 64 patients fit for discharge in 90 mins; 86 patients fit for discharge in 120 mins and 97 patients became fit for discharge in 150 mins.

\section{CONCLUSION}

Field block is found safe and fulfils the requirement of surgical relaxation and also best method as far as recovery profile is concerned in ambulatory surgery.

\section{KEYWORDS}

Field Block, Inguinal Herniorrhaphy, Outpatient Surgery.

HOW TO CITE THIS ARTICLE: Srinivasa VY, Shashikala TK. A clinical study of effect of field block on inguinal herniorrhaphy in an outpatient surgery. J Evolution Med Dent Sci 2016;5(1):23-26, DOI: 10.14260/jemds/2016/6

\section{INTRODUCTION}

Herniorrhaphy is one of the most commonly performed surgery, the aim of day care anaesthesia with field block is early ambulation, cost effectiveness, to reduce polypharmacy, post-operative pain relief, to reduce morbidity and infective complications. The essential criteria for anaesthetic technique of choice for a given surgery is patient's safety and surgeons comfort. These are not provided by SAB or GA. Hence to meet above requirement, the present study was undertaken. ${ }^{1,2}$

\section{MATERIAL AND METHODS}

After ethics committee approval, ASA class I and II patients aged between 18-60 years, with an escort at home as well as at the hospital. Pre-anaesthetic evaluation done on prior day of surgery with routine investigations such as $\mathrm{Hb} \%$, bleeding time, clotting time, blood urea, serum creatinine, fasting blood sugar, urine routine examination, ECG and screening chest, advised to take Tab alprazolam $0.25 \mathrm{mg}$ and Tab pantoprazole $40 \mathrm{mg}$ on previous night. On the day of surgery Midazolam 1mg given IV just before instituting field block.

Patients were given field block using 1\% lignocaine with adrenaline, $15 \mathrm{ml}$ of the solution was injected at $1.5 \mathrm{~cm}$ medial

Financial or Other, Competing Interest: None.

Submission 14-12-2015, Peer Review 16-12-2015,

Acceptance 30-12-2015, Published 01-01-2016.

Corresponding Author:

Dr. Velagalaburre Yalappa Srinivasa,

Associate Professor,

Department of Anaesthesiology,

Stone Building, K. R Hospital,

Mysore Medical College and Research Institute,

Mysore.

E-mail: drsrinivasvy@gmail.com

DOI:10.14260/jemds/2016/6 and superior to anterior superior iliac spine, $5 \mathrm{ml}$ injected at mid inguinal point, $5 \mathrm{ml}$ at pubic tubercle, about $10 \mathrm{ml}$ injected along the line of incision. If patient complains of pain, then additional $2 \mathrm{ml}$ injected at the neck of the inguinal hernial sac. If patient still complains of pain then pethidine $50 \mathrm{mg}$ given. The following scale was adopted to grade relaxation and analgesia.

\section{EXELLENT}

Patient comfortable with good surgical relaxation and analgesia.

\section{GOOD}

Patients requiring supplemental local anaesthesia at the neck of sac FAIR: Patients requiring supplemental local plus narcotic supplementation.

\section{POOR}

Inadequate anaesthesia requires $\mathrm{GA}^{3}{ }^{3}$

Pulse, BP, ECG, SPO2 Monitored, then patients were shifted to post -surgical intensive care annexure where;

I. Recovery were assessed by using modified Aldrete postanaesthetic recovery score. ${ }^{1,2}$

II. The postoperative pain relief and post-anaesthetic complications monitored. Using the following. 
Modified Aldrete Post-Anaesthetic Recovery (PAR) score for patients having ambulatory anaesthesia. ${ }^{1,2}$

\begin{tabular}{|c|c|c|}
\hline & & Score \\
\hline Activity & $\begin{array}{l}\text { Able to move } 4 \text { extremities voluntarily or on command } \\
\text { Able to move } 2 \text { extremities voluntarily or on command } \\
\text { Unable to move extremities voluntarily or on command }\end{array}$ & $\begin{array}{l}2 \\
1 \\
0\end{array}$ \\
\hline Respiration & $\begin{array}{c}\text { Able to breathe deeply and cough freely } \\
\text { Dyspnoea or limited breathing } \\
\text { Apnoeic }\end{array}$ & $\begin{array}{l}2 \\
1 \\
0\end{array}$ \\
\hline Circulation & $\begin{array}{c}\mathrm{BP}+/-20 \% \text { of pre-anaesthetic level } \\
\mathrm{BP}+/-20-49 \% \text { of pre-anaesthetic level } \\
\mathrm{BP}+/-50 \% \text { of pre-anaesthetic level }\end{array}$ & $\begin{array}{l}2 \\
1 \\
0\end{array}$ \\
\hline Consciousness & $\begin{array}{c}\text { Fully awake } \\
\text { Arousable on calling } \\
\text { Not responding }\end{array}$ & $\begin{array}{l}2 \\
1 \\
0 \\
\end{array}$ \\
\hline Oxygenation & $\begin{array}{c}\text { Able to maintain saturation }>92 \% \text { on room air } \\
\text { Needs oxygen to maintain saturation }>90 \% \\
\text { Saturation }<90 \% \text { even with oxygen }\end{array}$ & $\begin{array}{l}2 \\
1 \\
0\end{array}$ \\
\hline Wound dressing & $\begin{array}{l}\text { Dry and clean } \\
\text { Wet or marked but area constant } \\
\text { Growing area of wetness }\end{array}$ & $\begin{array}{l}2 \\
1 \\
0\end{array}$ \\
\hline Pain & $\begin{array}{c}\text { Pain free } \\
\text { Mild pain managed with oral therapy } \\
\text { Severe pain requiring parenteral therapy } \\
\end{array}$ & $\begin{array}{l}2 \\
1 \\
0 \\
\end{array}$ \\
\hline Ambulation & $\begin{array}{c}\text { Able to stand up and walk straight } \\
\text { Vertigo when erect } \\
\text { Dizziness when supine }\end{array}$ & $\begin{array}{l}2 \\
1 \\
0\end{array}$ \\
\hline $\begin{array}{l}\text { Fasting/ } \\
\text { Feeding }\end{array}$ & $\begin{array}{l}\text { Able to drink fluids } \\
\text { Nauseated } \\
\text { Nausea and vomiting }\end{array}$ & $\begin{array}{l}2 \\
1 \\
0\end{array}$ \\
\hline Urine output & $\begin{array}{c}\text { Has voided } \\
\text { Unable to void, but comfortable } \\
\text { Unable to void, but uncomfortable }\end{array}$ & $\begin{array}{l}2 \\
1 \\
0\end{array}$ \\
\hline
\end{tabular}

RESULTS

Age Distribution

\begin{tabular}{|c|c|}
\hline Age in Years & Number of Patients \\
\hline $18-25$ & 20 \\
\hline $26-30$ & 12 \\
\hline $31-35$ & 9 \\
\hline $36-40$ & 17 \\
\hline $41-45$ & 8 \\
\hline $46-50$ & 5 \\
\hline $51-55$ & 12 \\
\hline $56-60$ & 17 \\
\hline Total & $\mathbf{1 0 0}$ \\
\hline
\end{tabular}

Mean age distribution; 39.83 years with standard deviation of 13.79

\section{Weight Distribution}

\begin{tabular}{|c|c|}
\hline Weight in KG & Number of Patients \\
\hline $51-60$ & 48 \\
\hline $61-70$ & 47 \\
\hline $71-80$ & 4 \\
\hline $81-90$ & 1 \\
\hline Total & $\mathbf{1 0 0}$ \\
\hline \multicolumn{2}{|c|}{ Table 3 } \\
\hline
\end{tabular}

Weight distribution; mean weight $61.38 \mathrm{~kg}$ with standard deviation of 6.098
Quality of Analgesia and Relaxation

\begin{tabular}{|c|c|}
\hline & Number of Patients \\
\hline Excellent & 80 \\
\hline Good & 15 \\
\hline Fair & 2 \\
\hline Poor & 3 \\
\hline Total & $\mathbf{1 0 0}$ \\
\hline \multicolumn{2}{|c}{} \\
\hline
\end{tabular}

Quality of analgesia and relaxation; Excellent - 80, Good 15, Fair-2, Poor-3, Success rate 97\%, Failure rate 3\% Duration of Analgesia

\begin{tabular}{|c|c|}
\hline Time Range in Minutes & Number of Patients \\
\hline No of analgesia & 3 \\
\hline $151-160$ & 5 \\
\hline $161-170$ & 7 \\
\hline $171-180$ & 9 \\
\hline $181-190$ & 4 \\
\hline $191-200$ & 6 \\
\hline $201-210$ & 16 \\
\hline $210-220$ & 20 \\
\hline $221-230$ & 9 \\
\hline $231-240$ & 8 \\
\hline $241-250$ & 8 \\
\hline $251-260$ & 1 \\
\hline $261-270$ & 2 \\
\hline $271-280$ & 2 \\
\hline $281-290$ & Nil \\
\hline $291-300$ & Nil \\
\hline Total & 100 \\
\hline \multicolumn{2}{|c|}{ Table 5} \\
\hline
\end{tabular}

Duration of analgesia mean $\mathbf{- 2 1 2 . 3 8}$ mins , minimum of 160 mins and maximum of 280 mins 


\begin{tabular}{|c|c|c|}
\hline Time & Mean Score & Standard Deviation \\
\hline 0 minute & 15.01 & 1.243 \\
\hline 30 minutes & 15.44 & 1.249 \\
\hline 60 minutes & 16.75 & 0.903 \\
\hline 90 minutes & 17.59 & 0.985 \\
\hline 120 minutes & 18.53 & 1.149 \\
\hline 150 minutes & 18.92 & 0.8 \\
\hline \multicolumn{3}{|c|}{ Table 6 } \\
\hline
\end{tabular}

Modified Aldrete post anaesthetic. ${ }^{1}$ recovery score parameters- total score

\section{STATISTICAL METHOD}

Normally distributed continuous data were analyzed using students t-test, continuous data not normally distributed were analyzed by Mann-Whitney U-test. Categorical data were analyzed using the $\mathrm{X}^{2}$ test or Fisher's exact test where appropriate. Data presented as mean with standard deviation, median values with interquartile ranges, numbers or percentages $(\%) .^{3}$

\section{DISCUSSION}

The safety and effectiveness of hernia repair using local anaesthesia is more in teaching hospitals, because there is no need for admission so it avoids hospital stay as well as low cost to the patients. ${ }^{4}$

The advantages of local anaesthesia are safety, simplicity effectiveness, cost effectiveness, low rate of recurrence and infection. It is a method of choice in outpatient surgery and for minimising the cost of surgery. ${ }^{2,5,6}$

Many authors have used lignocaine alone for inguinal filed block (Prevoznik). ${ }^{7}$ but it is short acting.

Catherine J, et al. ${ }^{8}$ Using the above combination for institution of block found that there was an improvement in quality and duration of block.

\section{Concentration of Lignocaine with Epinephrine Solution}

\begin{tabular}{|c|c|c|c|c|c|c|}
\hline Study & $\begin{array}{c}\text { Total } \\
\text { Volume }\end{array}$ & ASIP & MIP & PT & SC & $\begin{array}{c}\text { Neck of } \\
\text { the Sac }\end{array}$ \\
\hline $\begin{array}{c}\text { Scott } \\
\text { early. }{ }^{9} \\
(1960)\end{array}$ & $35-40 \mathrm{ml}$ & $\begin{array}{c}5-10 \\
\mathrm{ml}\end{array}$ & - & $\begin{array}{c}3.5 \\
\mathrm{ml}\end{array}$ & $\begin{array}{c}5- \\
20 \mathrm{ml}\end{array}$ & $2 \mathrm{ml}$ \\
\hline $\begin{array}{c}\text { Dirking } \\
\text { et al. }{ }^{10} \\
(1992)\end{array}$ & $\begin{array}{c}55 \mathrm{ml} \\
(15 \mathrm{ml} \\
1 \%+ \\
40 \mathrm{ml} \\
0.5 \%)\end{array}$ & $25 \mathrm{ml}$ & $\begin{array}{c}5 \\
\mathrm{ml}\end{array}$ & $\begin{array}{c}5 \\
\mathrm{ml}\end{array}$ & $20 \mathrm{ml}$ & - \\
\hline $\begin{array}{c}\text { Present } \\
\text { study }\end{array}$ & $35-37 \mathrm{ml}$ & $15 \mathrm{ml}$ & $\begin{array}{c}5 \\
\mathrm{ml}\end{array}$ & $\begin{array}{c}5 \\
\mathrm{ml}\end{array}$ & $10 \mathrm{ml}$ & $2 \mathrm{ml}$ \\
\hline \multicolumn{7}{|c|}{ Table 7 } \\
\hline
\end{tabular}

Dosage and Concentration of Lignocaine with Epinephrine Dierking et al. ${ }^{10}$ used $1 \%$ lignocaine with epinephrine because epinephrine reduces plasma concentration of lignocaine and minimizes toxicity and prolonged post-operative pain relief. We have also used $1 \%$ lignocaine with epinephrine. It has been suggested that upper limit for lignocaine with epinephrine $7 \mathrm{mg} / \mathrm{kg}$. As a fairly large volume of drug required for the block the concentration kept at $1 \%$ for lignocaine in our study. As the mean weight of our patients $61.3 \mathrm{~kg}$ and mean volume used $35.3 \mathrm{ml}$, it became clear that the total dose of the lignocaine employed by us was well within the upper recommended limit.

\section{Quality of Analgesia and Relaxation}

Most of the authors have not commented regarding the quality of analgesia in field block even though they carried out surgery under local anaesthesia. Reid MF, et al. ${ }^{11}$ demonstrated good quality analgesia could be achieved by ilio-inguinal nerve block. Costa E. Silva classified the quality of analgesia as good, regular or bad, in the present study we graded $80 \%$ patients had excellent analgesia and relaxation. Only 15 patients had good analgesia and mild discomfort during sac manipulation which required supplementation.

With additional infiltration around neck of the sac with lignocaine $1 \%$ with epinephrine. Two (2\%) patients had analgesia graded as fair with mild pain during surgery. These patients were given pethidine $50 \mathrm{mg}$ to alleviate pain. Those had severe intolerable pain during surgery $(3 \%)$ requiring conversion to general anaesthesia. It has been observed by various authors that at the time of pulling of the sac, patients often complain of discomfort. ${ }^{9}$

This finding was observed in 15 patients in the present clinical study. Some authors used narcotic for pain relief during surgery. In the present study two patients required narcotic in addition to local anaesthetic supplementation.

As per Marshall et al. ${ }^{12}$ use of sedative dose of propofol has advantage of less nausea and vomiting, because of antiemetic action which in turn results faster discharge and cost effectiveness. In our study, we used propofol at a dose of $25-35 \mathrm{mg}$ at the time of Herniorrhaphy.

Callesen et al.13,14 studied 400 hernia patients who underwent surgery under local anaesthesia in whom $0-5 \%$ were converted to general anaesthesia. In our study, three patients $(3 \%)$ required general anaesthesia.

\section{Duration of Analgesia and Surgery}

\begin{tabular}{|c|c|}
\hline Duration of Surgery & Duration \\
\hline G. W. Dierling et al.(1992). ${ }^{10}$ & $48(25-90)$ minutes \\
\hline Mark Tverkoy et al.(1990).15 & $31+5$ minutes \\
\hline Present study & 32.58 minutes (15-60) \\
\hline \multicolumn{2}{|c|}{ Table 8} \\
\hline
\end{tabular}

Present study is similar to that of Mark Tverskoy. ${ }^{15}$ in this respect.

DC moore. ${ }^{16}$ stated that duration of analgesia with lignocaine can prolong up to 180 mins with adrenaline solution. As per Covino et al. ${ }^{17}$ duration of analgesic effect of lignocaine is 195+25 mins for brachial plexus block for local infiltration 35340 mins, duration can be prolonged up to $200 \%$ by addition of epinephrine. In the present study, mean duration of analgesia was 212 minutes (160 minutes to 280 minutes). So the present study correlates with the studies done by Covino et al. ${ }^{17}$

After shifting patients from operation theatre to postsurgical ICU annexure, the post anaesthetic recovery is assessed by using modified Aldrete Post Anaesthetic Recovery (PAR) score.1,2

The following are the studies done by various authors for hernia repair. Under filed block or monitored anaesthesia care as a day care anaesthesia. 


\begin{tabular}{|c|c|c|c|}
\hline Year & Study & & Result \\
\hline 1994 & $\begin{array}{l}\text { Ding, Yifing } \\
\text { et al.18 }\end{array}$ & $\begin{array}{l}\text { MAC } \\
\text { with } \\
\text { field } \\
\text { block }\end{array}$ & $\begin{array}{c}\text { Ambulation time } 86 \\
+18 \text { mins } \\
\text { Fit for discharge } \\
112+49 \text { minutes } \\
\end{array}$ \\
\hline 1995 & $\begin{array}{c}\text { A E Kark et } \\
\text { al. }{ }^{6}\end{array}$ & $\begin{array}{l}\text { Field } \\
\text { block }\end{array}$ & $\begin{array}{l}\text { Able to walk to room } \\
\text { assisted by nurse after } \\
1.5 \text { hours but fully able } \\
\text { to walk within } 3 \text { hours }\end{array}$ \\
\hline 2002 & $\begin{array}{c}\text { Jetfrey l } \\
\text { apfelbaum. }{ }^{19}\end{array}$ & $\begin{array}{l}\text { Mac } \\
\text { with } \\
\text { field } \\
\text { block }\end{array}$ & $\begin{array}{l}\text { Recovery time mean } \\
90 \text { mins } \\
\text { Recovery range } 20 \\
\text { mins to } 210 \text { mins } \\
\text { GA ; } 90 \text { mins to } \\
270 \text { mins }\end{array}$ \\
\hline 2004 & $\begin{array}{c}\text { Hangama et } \\
\text { al. }^{3}\end{array}$ & $\begin{array}{l}\text { Field } \\
\text { block } \\
\text { with } \\
\text { propofol }\end{array}$ & $\begin{array}{c}\text { Eye opening-7+9mins } \\
\text { Responds to } \\
\text { commands-10+9 mins } \\
\text { Orientation }-12+11 \\
\text { mins } \\
\text { Sitting up- } 53+27 \text { mins } \\
\text { Tolerate to oral fluids- } \\
60+26 \text { mins } \\
\text { Standing up- } 101+39 \\
\text { mins } \\
\text { Ambulating-102+ mins } \\
\text { Home readiness- } 115+ \\
43 \text { mins }\end{array}$ \\
\hline \multicolumn{4}{|r|}{$43 \mathrm{mins}$} \\
\hline
\end{tabular}

With respect to activity our study correlates with the study done by A E Kark, et al. ${ }^{6}$

Only three patients complained of pain and were managed with oral analgesics in our study, so it correlates with the study of G W Dierking et al.10

The mean ambulation score was 1.06 at 90 mins, 1.68 at 120 mins, 1.94 at 150 mins.

The mean score for the ability to drink fluid was 1.04 at 60 mins and 1.56 at 90 mins so it correlates with the study of Hangama et al. ${ }^{3}$

At 90 mins 64 patients were fit for discharge, at 120 mins 86 patients fit for discharge, at 150 mins almost all patients became fit for discharge.

So it correlates with the study done by Hangama et al. ${ }^{3}$

\section{CONCLUSION}

Lignocaine with adrenaline is effective for carrying out field block for outpatient anaesthesia and provides long duration of post-operative pain relief in comparison to general anaesthesia with mean duration of 212 mins.

Field block fulfils the requirements of surgical anaesthesia.

Field block is best method for outpatient anaesthesia because fit for discharge achieved early compared to general or spinal anaesthesia.

Outpatient anesthesia with field block avoids polypharmacy, is safe and economical because it avoids hospital stay.

\section{REFERENCES}

1. Aldrette JA. The post anaesthesia recovery score revisited: Journal of Clini anaesthesia, 1995;7(1):89-91.

2. Ian $\mathrm{S}$, Text book of day care anaesthesia, BMJ books, 2000: pp 1-34,105-106,120-121,139-140,180-206.

3. Hongama, Tang J, White PF, Zaentz A, Ronald H, Winder, et al. Perioperative Rofecoxib improves early recovery after outpatients herniorrhaphy, Anaesthesia Analgesia 2004;98:970-975.

4. Gianetta E, Cuneo S, Brunovitale, Camerini G, Marino P and Stella M. Anterior tension free repair of recurrent inguinal hernia under local anaesthesia, Annals of surgery 2000;231(1):132-136.

5. Amid PK, Shulman AG, Lichstein H. Local anaesthesia for inguinal hernia repair step by step procedure, Annals of surgery 2004;220(6):730-737.

6. Kark AE, Kurzer M, Waters KJ. Tension free mesh hernia repair; review of 1098 cases using local anaesthesia in a day unit, Ann R Coll Surg Engl 1995;77:299-304.

7. Prevoznik. Useful blocks in outpatient anaesthesia. International Anaesthesiology Clinic. Kurt F Schmidt, ed (1976); 14(2):91-95.

8. Sinnot J, Catherine BA, Cogswell P, Lawrence, Anthony JBS, Strichart RG; on mechanism by which epinephrine potentiates lidocaines peripheral nerve block, Anaesthesiology 2003; 98:181-188.

9. Scott E. A local anaesthesia for inguinal herniorrhaphy, survey of 50 patients. Am Jour of Surg 1960; 100:782-786.

10. Dierjing G, Dahl JB, et al. Effect of pre vs postoperative inguinal field block on postoperative pain after herniorrhaphy, BJA, 1992; 68:344-348.

11. Reid MF, Harris R, et al. Day care herniotomy in children, comparison of ilioinguinal nerve block and wound infiltration for postoperative analgesia; Anaesthesia 1987;42(6):658-661.

12. Scott IM, Chung, Frances. Discharge criteria and complications after ambulatory surgery. Anaesthesia analg; 1999;88:508-517.

13. Callesen $T$, Bech $K$, et al. The feasibility, safety and cost of infiltration anaesthesia for hernia repair. Anaesthesia 1998;54:31-35.

14. Callesen T, et al. Post herniorrhaphy pain. Anaesthesiology 1997;87(5):1219-1225.

15. Tverskoy M, Cozacovc, et al. Postoperative pain after inguinal herniorrhaphy with different types of anaesthesia; anaesthesia analgesia; 1990;70:29-35.

16. Moore DC. Regional block, $4^{\text {th }}$ edition, Springfield 1973, p 167.

17. Barash GP, Cullen F, Bruce, et al. Clinical anaesthesia 3rd edition 1997 pp 413-440, 4th edition pp1217-1238.

18. Ding Y, White PF. Post herniorrhaphy pain in outpatients after pre-incisional ilioinguinal and iliohypogastric nerve block during monitored anaesthesia care. Canadian Journal of Anaesthesia 1995;42(1):12-16.

19. Apfelbaum JI, et al. Eliminating intensive postoperative care in same day surgery patients using short acting anaesthetics, Anaesthesiology 2002;97:66-74. 